pag

Business School

WORKING PAPER SERIES

\begin{tabular}{l|l} 
Working Paper & $\begin{array}{l}\text { Integration versus segmentation in } \\
\text { Middle East North Africa equity } \\
\text { market: Time variations and currency } \\
\text { risk }\end{array}$ \\
Khaled Guesmi \\
Jean-Yves Moisseron \\
Frédéric Teulon
\end{tabular}

http://www.ipag.fr/fr/accueil/la-recherche/publications-WP.html

IPAG Business School

184, Boulevard Saint-Germain

75006 Paris

France 


\title{
Integration versus segmentation in Middle East North Africa equity market: Time variations and currency risk
}

\author{
Khaled Guesmi \\ Department of Finance, IPAG Business School, Paris \\ and EconomiX - University of Paris West Nanterre La Défense \\ E-mail: khaled.guesmi@ipag.fr \\ Jean-Yves Moisseron \\ IRD, Paris \\ E-mail: jean-yves.moisseron@ird.fr \\ Frédéric Teulon \\ Department of Finance, IPAG Business School, Paris \\ E-mail: f.teulon@ipag.fr
}

\begin{abstract}
This article investigates the dynamics of regional financial integration and its determinants in an international setting. We test a conditional version of the international capital asset pricing model (ICAPM) accounting for the deviations from purchasing power parity (PPP) as well as temporal variations in both regional and local sources of risk. Using data from seven major countries of the Middle East North Africa (MENA) region (Turkey, Israel, Egypt, Jordan, Syria, Kuwait and Tunisia), our results support the validity of ICAPM and indicate that the risk is regionally priced. Furthermore, we show that changes in the degree of regional stock market integration are explained principally by inflation, exchange rate volatility, rate spread variations, Short-term interest rate and world market dividend yield.
\end{abstract}

JEL Classification: F36; C32; G15

Keywords: Multivariate GARCH, Intra-regional integration, CAPM (Capital Asset Pricing Model) 


\section{Introduction}

Despite there is a consensus in the literature to say that the degree of emerging market integration varies over time (Bekaert and Harvey, 1995; Carrieri et al., 2007; Guesmi and Nguyen, 2011), empirical results are relatively divergent regarding the identification procedure of market integration determinants. Studies such as Bekaert and Harvey (1995, 1997), Adler and Qi (2003), and Hardouvelis et al. (2006) opt for an arbitrary choice of two or three financial and macroeconomic variables to model the dynamics of integration, while Carrieri et al. (2007) determine ex-post financial integration factors. The method proposed by Carrieri et al. (2007) may be subject to criticism because it arbitrarily introduces certain information variables to assess financial integration before they are considered as candidate variables that might explain financial integration.

Our study contributes to the existing literature by examining the dynamic regional integration with its determinants of seven major emerging markets in MENA (Turkey, Israel, Jordan, Egypt, Syria, Kuwait and Tunisia) together in the context of the partially integrated ICAPM whose theoretical foundations have recently developed in Arouri et al. (2012). We believe it makes sense to compare countries that do not belong to a single currency area but which are geographically close to each other, but unlike previous works, we firstly attempt to identify ex ante the driving forces behind the integration process of national stock markets from a set of local, regional and global variables. We also consider, in addition to the systematic risks associated with regional and local markets, changes in exchange rates which are, according to previous studies, a relevant source of risk in pricing emerging market assets (Adler and Dumas, 1983; Carrieri et al., 2007; Tai, 2007).

Our empirical results show that the inflation, exchange rate volatility, rate spread variations and world market dividend yield significantly affects changes in regional financial integration. They also point to the validity of the ICAPM and indicate that exchange rate risk is priced regionally. As in previous studies (Hardouvelis et al., 2006; Carrieri et al., 2007; Tai, 2007), we find that stock market integration involves through time and its changing patterns differ across studied markets.

The paper is organised in five sections. Section 2 presents the model with the estimation methodology used. Section 3 presents the data, while section 4 presents analyses the empirical findings. Section 5 concludes. 


\section{The Model}

Time varying capital market integration should be characterized on the basis of theoretical model that satisfies some properties: (i) the model should be rich enough to accommodate the continuously progressing international stock market from segmented to completely integrated markets, (ii) the model must characterize the changes in market integration through time owing to the impacts of the gradual removal of direct and indirect barriers to emerging market investments.

Consider first a fully integrated regional financial market in which purchasing power parity holds. Under these assumptions, several authors (Adler and Dumas, 1983) have extended the domestic CAPM of Sharpe (1964) to an international setting. Formally, a conditional version of the model can be written as:

$$
E_{t-1}\left(R_{i}^{c} / \psi_{t} \psi_{t-1}\right)=\delta_{r} \quad,{ }_{t e 1} C_{g}\left(R_{i}^{c}, \boldsymbol{R}_{r}^{c},{ }_{t e} / \psi_{t-1}\right)
$$

where $E_{t-1}\left(R_{i t}^{c}\right)$ is the excess return issued in country $i$, conditionally on a set of information $\psi_{t-1}$ that is available to investors up to time $t-1 . R_{\text {reg,t }}^{c}$ is the return on the regional market portfolio. Cov is the conditional covariance between the security's return and the region market returns. $\delta_{\text {reg,t-1}}$ refers to the conditionally expected regional price of covariance risk.

However, the existence of explicit restrictions to capital flows in emerging markets, and the empirical record (Bekaert and Harvey, 1995, 1997) suggests that emerging markets, may not be fully integrated. Errunza and Losq (1989) extend the ICAPM to account for mild segmentation between markets: a subset of the assets is available to all investors, while ownership of the remaining assets is restricted to a subset of the investors. Under these assumptions, expected returns are a function of two risk factors: exposure to global market risk and exposure to non diversifiable national risk. This model can be written as follows:

$$
E_{t-1}\left(R_{t t}^{c}\right)=\Lambda_{t-1}^{i}\left[\delta_{r e g, t-1} \operatorname{Cov}\left(R_{i t}^{c}, R_{\text {reg, }, t}^{c}\right)+\sum_{k=1}^{\prime} \delta_{k, t-1} \operatorname{Cov}\left(R_{i t}^{c}, t_{k t}^{c}\right)\right]+\left(1-\Lambda_{t-1}^{i}\right) \delta_{i, t-1} \operatorname{Var}\left(R_{i t}^{c}\right)
$$

where $t_{k t}^{c}$ is the return on the exchange rate of the currency of country $k$ against the currency of the reference country $c . \delta_{k, t-1}$ expresses the expected price of the exchange risk for currency $k . l$ is the number of markets included in the sample. Exponent $c$ indicates that 
returns are expressed in the currency of the reference country. $\delta_{\text {reg,t-1 }}$ refers to the conditionally expected regional price of covariance risk. $\Lambda_{t-1}^{i}$ is the conditional probability of transition between segmentation and integration states, which falls within the interval $[0,1]$ and can be thus interpreted as a conditional measure of integration of market $i$ into the regional market. If $\Lambda_{t-1}^{i}=1$, only the covariance risk is priced and the strict segmentation hypothesis is rejected. If $\Lambda_{t-1}^{i}=0$, the unique source of systematic risk is the variance and the pricing relationship in a strictly segmented market applies.

At the empirical stage, the pricing formula in Equation (2) will be simultaneously estimated for the regional market and for four emerging market. That is, we have a system of two equations,

where the expected return on the regional market portfolio is given by :

$$
\begin{aligned}
& E_{t-1}\left(R_{\text {regt }}^{c}\right)=\lambda_{\text {reg, },-1} \operatorname{Var}_{t-1}\left(R_{\text {eg, }, t}^{c}\right)+\lambda_{T R, t-1} \operatorname{Cov}_{t-1}\left(R_{\text {St }}^{c}, t_{T R t}^{c}\right)+\lambda_{I S t-1} \operatorname{Cov}_{t-1}\left(R_{t t}^{c}, t_{I S}^{c}\right) \\
& +\lambda_{J O, t-1} \operatorname{Cov}_{t-1}\left(R_{s t}^{c}, t_{J O t}^{c}\right)+\lambda_{E G, t-1} \operatorname{Cov}_{t-1}\left(R_{s t}^{c}, t_{E G t}^{c}\right)+\lambda_{S Y, t-1} \operatorname{Cov}_{t-1}\left(R_{t t}^{c}, t_{S n}^{c}\right) \\
& +\lambda_{K W, t-1} \operatorname{Cov}_{t-1}\left(R_{t, t}^{c}, t_{K W}^{c}\right)+\lambda_{T N, t-1} \operatorname{Cov}_{t-1}\left(R_{f t}^{c}, t_{T N t}^{c}\right)
\end{aligned}
$$

and the expected return for market $i$ is expressed as follows :

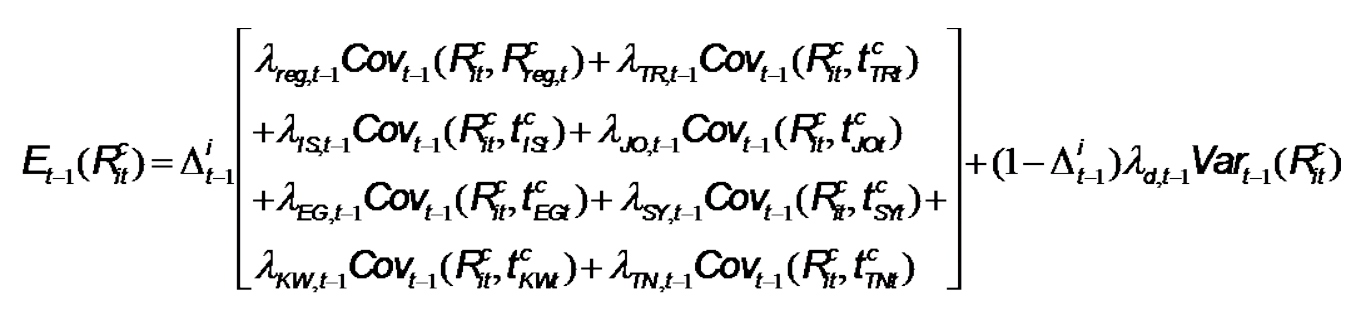

with $i=T R$ (Turkey), IS(Israel), JO (Jordan), SY (Syria), EG (Egypt), KW (Kuwait) and TN (Tunisia).

In Equation (4), $t_{T R}^{c}, t_{I S}^{c}, t_{J O t}^{c}, t_{E G t}^{c}, t_{S H}^{c}, t_{K W_{t}}^{c}$ and $t_{T^{*}}^{c}$ are respectively the returns on the real exchange rate indices of the four markets under consideration, and $\lambda_{\mathbb{T R}, t-1}, \lambda_{I S, t-1}, \lambda_{J, t-1}, \lambda_{\mathrm{EG}, t-1}, \lambda_{\mathrm{SY}, t-1}, \lambda_{K W, t-1}$ and $\lambda_{T N, t-1}$ refer to the expected prices of the exchange rate risk. 
The degree of integration of country $i$ into the regional market, $\Lambda_{t-1}^{i}$, is modelled by using an exponential function that satisfies the condition $0 \leq \Lambda_{t-1}^{i} \leq 1$, as follows $\Delta_{t-1}^{i}=\operatorname{Exp}\left(-\left|g_{i} X_{i, t-1}\right|\right)$, where $X_{i, t-1}$ is the vector of information variables available at time $t-1$ that are susceptible to drive the integration degree of country $i$.

More specifically, the econometric specification of the model to be estimated, i.e., Equations (3) and (4), is characterized by the following system :

$$
\begin{aligned}
& r_{i t}=\Lambda_{t-1}^{i}\left(\lambda_{\text {reg,t-1}} h_{\text {ireg,t }}+\lambda_{T R, t-1} h_{i T R, t}+\lambda_{I S, t-1} h_{i I S, t}+\lambda_{J O, t-1} h_{i J O, t}+\lambda_{E G, t-1} h_{i E G, t}+\lambda_{S Y, t-1} h_{i S Y, t}\right. \\
& \left.+\lambda_{K W, t-1} h_{i K W_{t} t}+\lambda_{T N, t-1} h_{i T N, t}\right)+\left(1-\Lambda_{t-1}^{i}\right) \lambda_{i, t-1} h_{i j, t}+\varepsilon_{i t} \\
& \varepsilon_{t} / \psi_{t-1} \sim N\left(0, H_{t}\right)
\end{aligned}
$$

where $r_{i t}$ refers to the $(15 \times 1)$ vector of excess returns which are assumed to be normally distributed. $H_{t}$ is the variance-covariance matrix of returns at time $t$.

$$
H_{t}=D_{t} R_{t} D_{t} \text {, where } D_{t}=\operatorname{diag}\left\{\sqrt{h_{i, t}}\right\}
$$

$R_{t}$ is assumed to be conditionally multivariate normal. The key here is that $R_{t}$ is a correlation matrix that varies over time, distinguishing the model from the constant conditional correlation model which uses $D_{t} R D_{t}$. Then $H_{t}$ is the conditional covariance matrix. $D_{t}$ is a diagonal matrix of conditional, i.e., time varying standard deviations, which are obtained form the univariate GARCH models. Therefore, for a pair of markets $i$ and $j$, their conditional correlation at time $t$ can be written as

$$
\rho_{i j t}=\frac{\left(1-\theta_{1}-\theta_{2}\right) \bar{q}_{i j}+\theta_{1} u_{i, t-1} u_{j, t-1}+\theta_{2} q_{i j, t-1}}{\left(\left(1-\theta_{1}-\theta_{2}\right) \bar{q}_{i i}+\theta_{1} u_{i, t-1}^{2}+\theta_{2} q_{i i, t-1}\right)^{1 / 2}\left(\left(1-\theta_{1}-\theta_{2}\right) \bar{q}_{j j}+\theta_{1} u_{j, t-1}^{2}+\theta_{2} q_{j j, t-1}\right)^{1 / 2}}
$$

where $q_{i j}$ is the element on the $i^{\text {th }}$ line and $j^{\text {th }}$ column of the matrix $Q_{t}$.

Following Bekaert and Harvey (1995) and Hardouvelis et al. (2006), we adopt a two-stage procedure to estimate the pricing system (5) since the simultaneous estimation of the full model is not feasible given a large number of unknown parameters. We first estimate a subsystem of seven equations for excess returns on regional market and seven real exchange rate indices. This stage allows us to obtain the conditional variance of regional market and 
real exchange rate, their conditional covariances as well as the prices of regional market and exchange rate risks. In the second stage, we estimate the price of local market risk and the time-varying level of integration for each emerging market region in the system (5) by imposing the estimators obtained from the first stage. Note that by doing so we explicitly maintain the same prices of regional market and exchange rate risks across different emerging market. The estimation of the vector of unknown parameters $(\theta)$ is carried out by the quasimaximum likelihood estimation (QMLE) method which is robust to departures from normality of return series under some regular conditions (Bollerslev and Wooldridge, 1992).

\section{Explanatory factors of financial integration}

\subsection{Stock market returns and exchange rate}

This study investigates the regional integration process of seven emerging market (Turkey, Israel, Egypt, Jordan, Syria, Kuwait and Tunisia). Monthly data are collected for stock market indices, regional stock market index, and real effective exchange rate indices over the period from March 31, 1996 to March 31, 2008. All returns are expressed in US dollars and are converted into excess returns by subtracting the one-month Eurodollar interest rate, taken as the risk-free rate in our study. We use the real effective exchange rate (REER) index to represent the exchange rate risk since variations in the inflation rates of emerging markets are much significant in comparison to those in the exchange rates.

\subsection{Instruments for the dynamic measure of financial integration}

There is a lack of information regarding the determinant factors of financial integration in the literature. Consequently, the selection of these potential variables is based on prior work and economic intuition. We do not impose factors a priori and all the factors are eligible. Thus, we consider a wide range of factors likely to affect the level of financial integration and we test their significance. There are two types of factors: direct and indirect. The first have been considered as the main causes of financial segmentation such as tariff barriers (customs duty) and non tariff barriers (all other obstacles to imports of foreign goods and capital controls). Indirect barriers, however, are independent of political decisions. These could include financial crises, macroeconomic instability and currency exchange risks, for example. While new information and communication technologies, together with the international standardisation of financial products and accounting standards have considerably reduced both sources of information asymmetry and information processing transaction costs, 
economic and monetary instability appears to have increased with financial globalisation. Nishiotis (2004) compared the effects of direct and indirect barriers on the evaluation of pension funds. He showed that the impact of indirect barriers is significantly higher than that of direct barriers. Bekaert and Harvey (1997, 2000), Bhattacharya and Daouk (2002) choise many candidate factors that cause the movements in the degree of regional financial integration. For exemple, the degree of market openness measured by the ratio of imports plus exports to GDP, the development level of the local stock market as measured by the ratio of market capitalization to GDP, the industrial production, inflation rate, the short-term interest rate, the interest rate spread, the long-term interest rate, the exchange rate volatility, the economic growth rate, the current account deficit, the local and regional market returns, the local market dividend yield, the regional market dividend yield, the world interest rate, the global market return and the global market dividend yield. It is expected that these factors, being important determinants of cross-border investment flows and international market convergence, have an explanatory power for the non-monotonous process of financial integration.

\section{Empirical results}

\subsection{Regional integration factors}

To identify the determinants of financial integration, we estimate the model (5) jointly for all considered markets and for each factor at a time using the nonlinear least squares method. Following Bhattacharya and Daouk (2002), we impose the same and constant coefficients in the equation to measure the degree of integration for all markets. This assumption permits us to capture the impact of each candidate factor on the integration of individual markets. It is also worth noting that our basic model uses the bilateral exchange rates against the U.S. dollar. The set of considered factors includes the local, regional and global variables that may influence the degree of regional financial integration. The estimation results are reported in Table 1. We find that the inflation, exchange rate volatility, rate spread variations, Short-term interest rate and world market dividend yield exert a significant impact on financial integration. Our findings thus corroborate those of previous studies (Bekaert and Harvey, 1995, Bhattacharya and Daouk, 2002; Adler and Qi, 2003; Hardouvelis et al., 2006). 
Table 1. The determinants of regional stock market integration

\begin{tabular}{|c|c|c|c|c|c|c|}
\hline & \multicolumn{2}{|c|}{$\begin{array}{l}\text { Bilateral exchange rates } \\
\text { against the dollar (A) }\end{array}$} & \multicolumn{2}{|c|}{$\begin{array}{l}\text { Bilateral exchange rates } \\
\text { against the TRY (B) }\end{array}$} & \multicolumn{2}{|c|}{$\begin{array}{l}\text { Real effective } \\
\text { exchange rate index } \\
\text { (C) }\end{array}$} \\
\hline & $g_{0}$ & $g_{1}$ & $g_{0}$ & $g_{1}$ & $g_{0}$ & $g_{1}$ \\
\hline \multirow[t]{2}{*}{ Degree of trade openness } & -0.233 & -0.351 & -0.033 & 0.005 & -0.622 & 0.255 \\
\hline & $(0.813)$ & $(-0.425)$ & $(0.306)$ & $(0.911)$ & $(1.541)$ & $(2.112)$ \\
\hline \multirow[t]{2}{*}{ Development of the stock market } & -4.96 & -1.25 & -0.143 & 0.020 & 2.384 & 0.00137 \\
\hline & $(5.62)$ & $(5.545)$ & $(0.432)$ & $(0.030)$ & $(2.889)$ & $(0.875)$ \\
\hline \multirow{2}{*}{$\begin{array}{l}\text { Local market industrial } \\
\text { production }\end{array}$} & 0.498 & -4.596 & 0.0783 & 0.137 & 0.0305 & 0.008 \\
\hline & $(0.475)$ & $(5.147)$ & (0.184) & $(-0.755)$ & $(0.208)$ & $(0.0479)$ \\
\hline \multirow[t]{2}{*}{ World industrial production } & 2.704 & 1.508 & $-46.5^{* * *}$ & $-27.54 * * *$ & 1.080 & -5.589 \\
\hline & $(1.778)$ & $-(1.521)$ & $(8.006)$ & $(8.657)$ & $(0.114)$ & $(-4.761)$ \\
\hline \multirow[t]{2}{*}{ Industrial growth rate deviation } & -4.34 & 0.981 & $-4.34 * * *$ & 0.781 & -0.283 & 0.255 \\
\hline & $(3.82)$ & $(0.920)$ & $(-0.82)$ & $(0.8200)$ & $(-0.425)$ & 0.5491 \\
\hline \multirow[t]{2}{*}{ Inflation } & $-6.824 * *$ & $-3.50 * *$ & -0.099 & $0.802 * * *$ & 1.961 & -24.112 \\
\hline & $(-1.69)$ & $(1.817)$ & $(-0.347)$ & $(0.020)$ & $(1.543)$ & $(19.231)$ \\
\hline \multirow[t]{2}{*}{ Exchange rate volatility } & $-6.75 * * *$ & $-5.68 * * *$ & 1.800 & $1.900 *$ & $-3.955 * * *$ & $-4.597 * * *$ \\
\hline & $(-6.34)$ & $(-2.101)$ & $(6.255)$ & $(0.0001)$ & $(-1.183)$ & $(-2.17)$ \\
\hline \multirow[t]{2}{*}{ Economic growth } & -0.242 & $17.947 * * *$ & $-6.26 * * *$ & $-6.632 * * *$ & 0.288 & 0.001 \\
\hline & $(-0.335)$ & $(0.792)$ & $(-3.109)$ & $(-3.002)$ & $(0.474)$ & $(0.030)$ \\
\hline \multirow[t]{2}{*}{ Local market dividend yield } & 0.216 & -0.937 & -0.233 & $17.285^{* * *}$ & 0.080 & -0.140 \\
\hline & $(0.698)$ & $(-0.646)$ & $(0.337)$ & $(0.754)$ & $(0.18)$ & $(-0.76)$ \\
\hline \multirow[t]{2}{*}{ Regional market dividend yield } & $1.312 * * *$ & $0.087 * * *$ & -0.333 & $0.095 * * *$ & 0.043 & 0.075 \\
\hline & $(0.6217)$ & $(0.001)$ & $(-0.428)$ & $(0.0145)$ & $(0.213)$ & $(0.078)$ \\
\hline \multirow[t]{2}{*}{ World market dividend yield } & $-2.504^{* *}$ & $-0.607 *$ & 0.218 & -1.197 & -0.200 & 0.822 \\
\hline & $(-2.047)$ & $-(1.99)$ & $(0.504)$ & $(0.45)^{* * *}$ & $(-0.540)$ & $(0.723)$ \\
\hline \multirow[t]{2}{*}{ Dividend yields deviation } & -0.089 & 0.659 & 0.2538 & $0.149-$ & -0.290 & -0.023 \\
\hline & $(-0.857)$ & $(0.721)$ & $(0.854)$ & $(0.880)$ & $(-0.771)$ & $(-0.364)$ \\
\hline \multirow[t]{2}{*}{ Short-term interest rate } & $-0.139 * * *$ & $1.922 * * *$ & $0.182 * * *$ & $-1.106^{* * *}$ & 0.498 & -4.596 \\
\hline & $(0.017)$ & $(0.728)$ & $(0.002)$ & $(0.703)$ & $(0.475)$ & $(5.147)$ \\
\hline \multirow[t]{2}{*}{ Long-term interest rate } & 1.800 & 1.900 & -0.141 & 0.205 & 0.112 & 0.760 \\
\hline & $(6.255)$ & $(1.700)$ & $(0.3988)$ & $(0.941)$ & (1.133) & $(0.678)$ \\
\hline \multirow[t]{2}{*}{ Interest rate spread } & $0.99 * * *$ & $0.900 * * *$ & $0.360 * * *$ & $-2.121 * * *$ & -0.0216 & -0.0401 \\
\hline & $(0.474)$ & $(0.0001)$ & $(0.076)$ & $(1.055)$ & $(0.0541)$ & $(0.543)$ \\
\hline \multirow[t]{2}{*}{ Current account deficit } & -0.283 & 0.255 & -0.383 & 0.155 & -0.129 & 0.0458 \\
\hline & $(0.425)$ & 0.54906 & $(0.525)$ & 0.74906 & $(0.169)$ & $(0.775)$ \\
\hline \multirow[t]{2}{*}{ Local market return } & 1.706 & 0.0010 & 2.480 & 5.654 & 5.530 & 1.127 \\
\hline & $(1.643)$ & $(0.0001)$ & $(4.431)$ & (7.654) & $(5.637)$ & (3.142) \\
\hline \multirow[t]{2}{*}{ Regional market return } & -0.0216 & -0.0401 & 3.914 & 0.789 & -2.342 & 3.603 \\
\hline & $(0.0541)$ & $(0.543)$ & (2.825) & $(0.828)$ & (1.499) & (1.469) \\
\hline \multirow[t]{2}{*}{ World market return } & -0.383 & 0.155 & 0.285 & 0.214 & -0.286 & 0.399 \\
\hline & $(0.524)$ & $(0.748)$ & $(0.762)$ & $(0.384)$ & $(0.641)$ & $(0.315)$ \\
\hline \multirow[t]{2}{*}{ World interest rate } & 1.706 & 0.0002 & 2.480 & 5.654 & 5.530 & 1.127 \\
\hline & (1.643) & $(0.0001)$ & (4.431) & (4.654) & (5.637) & (3.142) \\
\hline
\end{tabular}

Notes: We estimate the system (5) for all countries by imposing the same prices of exchange rate and regional market risks as well as conditional variances and covariances obtained during the first estimation stage. We consider one candidate factor for financial integration at a time. Parts (A), (B) and (C) report the estimation results respectively for the bilateral exchange rates against the U.S. dollar, the bilateral exchange rates against the Turkish Lira (TRY), and real effective exchange rate index. The numbers in parenthesis are the associated standard deviations. ${ }^{*},{ }^{* *}$, and ${ }^{* * *}$ indicate significance at the $10 \%, 5 \%$ and $1 \%$ levels respectively. Trade openness is the ratio of total trade with the world to nominal GDP. Stock market development is measured by the ratio of market capitalization to nominal GDP. Industrial production refers to the level of industrial production in logarithm. Differences in industrial production growth rates refer to the difference between growth rates of the country i's industrial production and the industrial production of the G7 countries. Short-term interest rate can be the T-bill rate or the interbank rate. Interest rate spread is measured by the difference between the longterm and short-term interest rates. Differences in dividend yield refer to the difference between the country i's and the world dividend yields. Exchange rate volatility is the conditional volatility that is estimated by applying an $\mathrm{AR}(1)-\mathrm{GARCH}(1,1)$ model to the exchange rates in logarithm. Economic growth rate is measured by the logarithm of the changes in the GDP. Current account deficit refers to the logarithm of the differences between exports and imports. 
Most prior empirical work has used the U.S. dollar as the reference currency (Bekaert and Harvey, 1997; Griffin, 2001; Karolyi and Stulz, 2002; Dumas et al., 2003; Barr and Priestley, 2004; Carrieri et al., 2007). However, when dealing with regional integration, the reference portfolio is the regional market, which suggests that the estimation results may be sensitive to a benchmark currency at regional level. Among our sample countries, Turkey has the largest share of regional GDP and its currency (Turish Lira (TRY)) is most commonly used in international and regional trade. Therefore, we consider the TRY as the new reference currency instead of the U.S. dollar to study the impact of changing the reference currency on the estimation of financial integration determinants. Indeed, we re-estimate the whole system (5) for each integration factor. The results are presented in part (B) of Table 1. It can be observed that the results are almost the same as those obtained with the U.S. dollar as reference currency.

We also test the sensitivity of our results when bilateral exchange rates are replaced by a real effective exchange rate index. ${ }^{1}$ In this case, our empirical model incorporates two common risk premiums for all markets: regional market risk premium and exchange risk premium. The results, presented in Part $\mathrm{C}$ of Table 1, show that only the exchange rate volatility explain the evolution of regional financial integration.

In short, the key factors driving financial integration remain relatively invariant with regard to the change in reference currency, but change significantly when the real effective exchange index is considered. These findings help explain the result divergence among previous studies with regard to the number and nature of integration factors.

\subsection{Stock Market Integration Analysis}

The degree of regional integration differs from one market to another, reflecting the heterogeneity of the economic and monetary policies followed by the member countries in the region. The Egyptien stock market is the most integrated one (88.7\%), followed by Jordan (69.9\%), Turkey (63.1\%), Israel (58.1\%), Syria (53.1\%), Kuwait (43.1\%) and Tunisia $(42.2 \%)$.

\footnotetext{
${ }^{1}$ Adler and Qi (2003) also adopt this approach in their study.
} 
Table 2. Degree of financial integration

\begin{tabular}{llll}
\hline & $\Delta$ mean & $\Delta$ max & $\Delta$ min \\
\hline Turkey & $\begin{array}{l}0.631^{* * *} \\
(0.034)\end{array}$ & 0.664 & 0.405 \\
\hline \multirow{2}{*}{ Egypt } & $\begin{array}{l}0.887^{* * *} \\
(0.048)\end{array}$ & 0.800 & 0.622 \\
\hline Jordan & $\begin{array}{l}0.692^{* * *} \\
(0.078)\end{array}$ & 0.827 & 0.486 \\
\hline Israel & $\begin{array}{l}0.581^{* * *} \\
(0.030)\end{array}$ & 0.661 & 0.465 \\
\hline Syria & $\begin{array}{l}0.531^{* * *} \\
(0.020)\end{array}$ & 0.831 & 0.465 \\
\hline Kuwait & $\begin{array}{l}0.431^{* * *} \\
(0.016)\end{array}$ & 0.641 & 0.401 \\
\hline Tunisia & $0.422^{* * *}$ & 0.831 & 0.465 \\
\hline
\end{tabular}

Notes:*, ** and ***, show that the coefficients are significantly different from zero at the $10 \%, 5 \%$ and $1 \%$ threshold using the Student test. The values between brackets are the standard deviations. The degree of integration is thus modelled as follows: $\Delta_{t-1}^{i}=\operatorname{Exp}\left(-\alpha_{0}+\alpha_{1} I F L_{i, t-1}+\alpha_{2} E R F_{i, t-1}+\alpha_{3} R P_{i, t-1}+\alpha_{4} S T_{i, t-1}+\alpha_{5} W M D_{i, t-1}\right)$. IFL, ERF, RSP,STI and WMD are respectively inflation, exchange rate fluctuations, rate spread variations, Shortterm interest rate and world market dividend yield.

An analysis of the Figure 1 shows that Egypt, Turkey, Kuwait and Tunisia have experienced a significant increase in the degree of integration in recent years. This market recorded effectively levels of integration above 70\% during the subperiod 2000-2007. No specific pattern has been observed for Syria, but this market remain poorly integrated with the regional one. Moreover, the high level of regional financial integration may be explained by an increase in financial flows. Egypt, Jordan and Turkey, for example, are attracted by the proximity of the most developed countries in the region like Kuwait and Israel (notably, in terms of GDP) and, on the other hand, less developed countries become attractive investments for the more developed countries in the region. From this perspective, the heterogeneity of the degree of development in the MENA area promotes intra-regional integration. 
Figure 1 : Regional Integration

Egypt

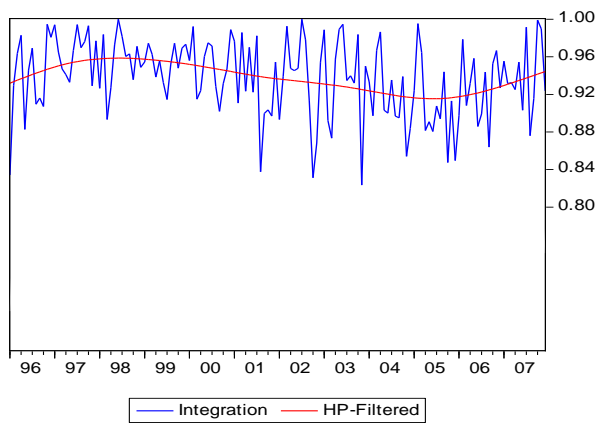

Jordan

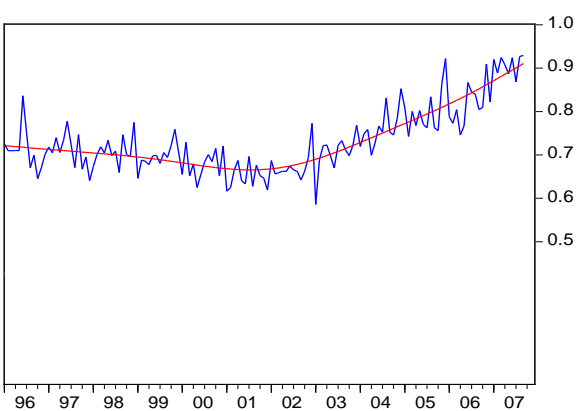

— Integration — HP-Filtered

Tunisia

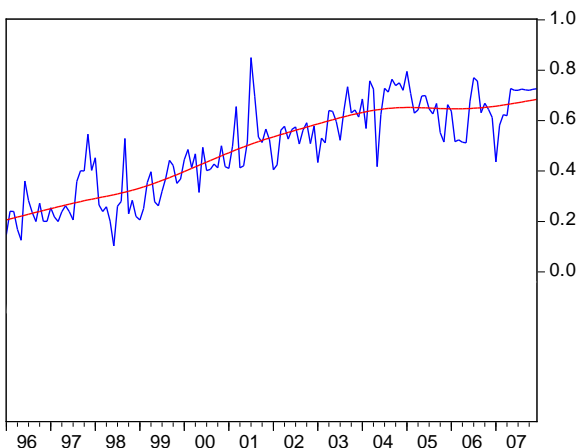

— Integration — HP-Filtered
Israel

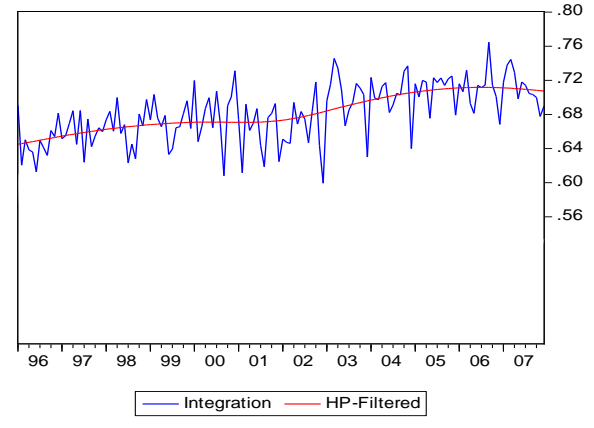

Turkey

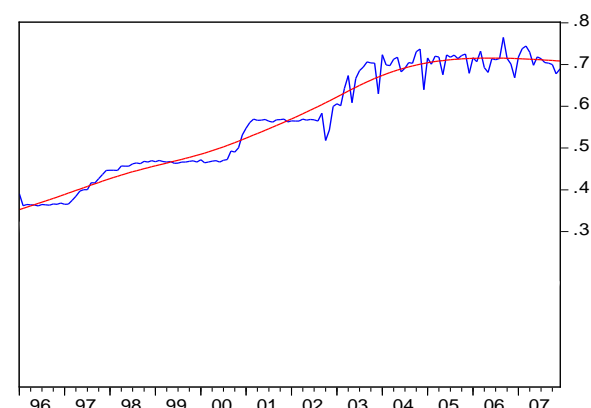

- Integration — HP-Filtered

Kuwait

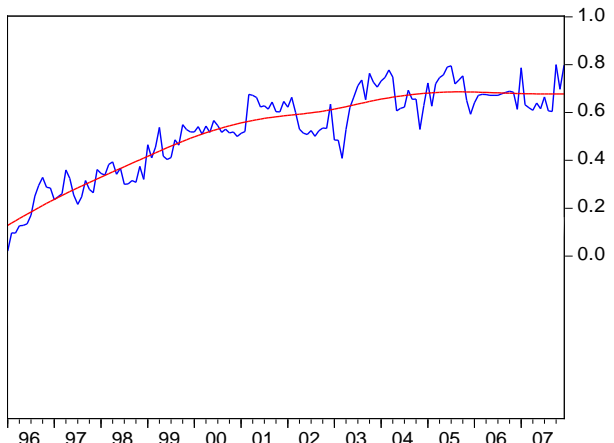

— Integration — HP-Filtered

Syria

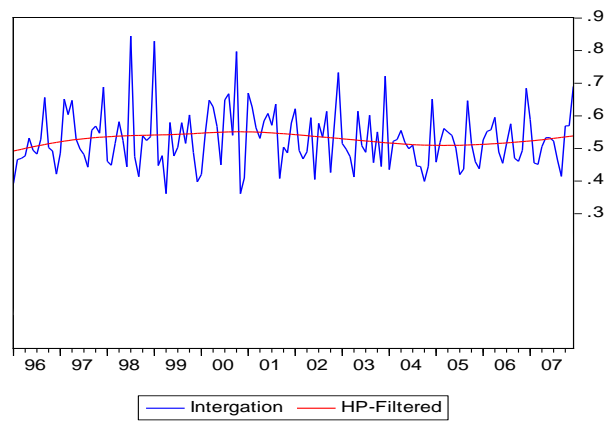




\section{Conclusion}

We developed a conditional ICAPM in the presence of exchange rate risk to identify factors that may influence the degree of financial integration for seven major markets in MENA region (Turkey, Israel, Jordan, Egypt, Syria, Kuwait and Tunisia). The findings are then used to study the dynamics of financial integration. Our empirical analysis is conducted on the basis of a nonlinear framework which relies on the multivariate DCC-GARCH model.

By allowing the prices of risk and the level of market integration to vary through time, we show inflation, exchange rate volatility, rate spread variations, Short-term interest rate and world market dividend yield are the most important determinants of regional financial integration. Moreover, the degree of market integration admits frequent changes over the study period and its dynamic patterns differ greatly across the markets under consideration. While the integration of stock market with the regional market tends to rise in recent years but does not record any particular trend upward or downward for Syria.

\section{References}

Adler, M., Dumas, B., 1983. International Portfolio Selection and Corporation Finance: A Synthesis, Journal of Finance 38, 925-84.

Adler, M., Qi, R., 2003. Mexico’s Integration into the North American Capital Market, Emerging Economic Review 4, 91-120.

Arouri, M., Nguyen, D.K., Pukthuanthong, K., 2012. An international CAPM for partially integrated markets: Theory and empirical evidence. Journal of Banking and Finance 36, 2473-2493.

Barr, D., Priestley, R., 2004. Expected Returns, Risk and the Integration of International Bond Markets, Journal of International Money and Finance 23, 71-97.

Bekaert, G., Harvey, C., 1995. Time Varying World Market Integration, Journal of Finance 50 (2), 403-444.

Bekaert, G., Harvey, C., 1997. Emerging Equity Market Volatility, Journal of Financial Economics 43, 29-77.

Bekaert, G., Harvey, C., 2000. Foreign Speculators and Emerging Equity Markets. Journal of Finance 55, 565-613.

Bhattacharya, U., Daouk, H., 2002. The World Price of Insider Trading, Journal of Finance 57, 75108.

Bollerslev, T., Wooldrige, J.M., 1992. Quasi-maximum Likelihood Estimation and Inference in Dynamic Models with Time-Varying Covariances, Econometric Review 11, 143-172.

Carrieri, F., Errunza, V., Majerbi, B., 2007. Does Emerging Markets Exchange Risk affect Global Equity Prices?, Journal of Financial and Quantitative Analysis 41 (3), 511-540.

Dumas, B., Harvey C. \& Ruiz P., 2003. Are Correlations of Stock Returns Justified by Subsequent Changes in National Outputs ?, Journal of International Money and Finance 22, 777-811.

Errunza, V., Losq, E., 1989. Capital Flows Controls, International Asset Princing Investors' Welfare: a Multicountry Framework, Journal of Finance 44 (4), 1025-1037.

Griffin, J., 2002. Are the Fama and French Factors Global or Country-Specific?, The Review of Financial Studies 15 (3), 783-803.

Guesmi, K., Nguyen, D.K., 2011. How strong is the global integration of emerging market regions? An empirical assessment, Economic Modelling 28 (6), 2517-2527. 
Hardouvelis, G., Malliaropoulos, P., Priestley, D., 2006. EMU and Stock Market Integration, Journal of Business 79, 365-392.

Karolyi, A., Stulz, R., 2002. Are Financial Assets Priced Locally or Globally?, in G. Constantinides, M. Harris \& R. Stulz (eds), Handbook of the Economics of Finance, North-Holland.

Nishiotis, G., 2004. Do Indirect Investment Barriers contribute to Capital Market Segmentation?”, Journal of Financial and Quantitative Analysis 39 (3), 613-630.

Sharpe, W., 1964. Capital Asset Prices: A Theory of Market Equilibrium under Conditions of Risk, Journal of Finance 9, 725-742.

Tai, C., 2007. Market integration and contagion: Evidence from Asian emerging stock and foreign exchange markets. Emerging Markets Review 8, 264-283. 